\title{
Coming of Age with HIV: A Need for Disclosure of HIV Diagnosis among Children/Adolescents
}

\author{
Seema Sahay \\ Scientist-E, National AIDS Research Institute, Pune, India.
}

${ }^{*}$ Corresponding author: Seema Sahay, National AIDS Research Institute, Pune, India; Fax: 91-20-27121071; Tel:

91-20-27331200; E-mail: ssahay@nariindia.org

Received Date: September 04, 2013, Accepted Date: October 01, 2013, Published Date: October 03, 2013

Citation: Seema Sahay (2013) Coming of Age with HIV: A Need for Disclosure of HIV Diagnosis among Children/Adolescents J HIV AIDS Infect Dis 1: 1-7.

\section{Introduction}

The success in the prevention and treatment of Paediatric HIV in high resource countries, and later on in low resource countries, has changed the face of the HIV epidemic in children. A number of clinical, social and psychological issues arise among children who acquire perinatal HIV infection. Paediatric survival post-HIV infection without anti-retroviral treatment was calculated using pooled data from 12 studies showed that children infected perinatally had a much higher risk of dying than those infected through breastfeeding [1]. Now most children live longer than before [2]. However, these successes pose new challenges as children with perinatal HIV infection survive into adolescence and adulthood. Hence the perinatally infected children, who are HIV survivors, are 'coming of age' and need to meet biological and psychosocial challenges of life. Increased survival of HIV infected children is associated with challenges in maintaining adherence to what is likely life-long therapy $[3,4]$. One of the biggest psychosocial challenges that health care providers and parents face is the disclosure of HIV diagnosis among children [5]. Children with a variety of chronic diseases, including those with cancer, have exhibited better coping skills and fewer psychosocial problems when appropriately informed about the nature and consequences of their illness [6,7]. Further, the World Health Organization (WHO) recommends the disclosure of HIV diagnosis to children (WHO 2011).

Perinatal HIV-1 infection has been reported to interfere with sexual maturation. Associated linear growth failure may cause psychological stress [8]. Another recent study has shown that Highly Active Anti-Retroviral Therapy (HAART) might have increased the longevity of children but these children remain at increased risk of psychosocial problems and impaired social functioning [9]. The disclosure intervention would be a step towards preparing HIV infected children for

C 2013 The Authors. Published by the JScholar under the terms of the Creative Commons Attribution License http://creativecommons.org/licenses/ by/3.0/, which permits unrestricted use, provided the original author and source are credited. adolescence and subsequently adulthood. A number of studies-in high and low resource settings-have found that many perinatally infected adolescents may not be aware of their HIV status $[2,10,11]$.The intermittent illnesses is expected in HIV infected children [12] and therefore they would require more visit to doctors. Hence instead of inadvertent disclosure of HIV diagnosis, a systematic disclosure would be important for HIV infected children/ adolescents. There are no effective disclosure guidelines available especially for resource limited settings. A review was done to systematically understand the gaps and argue out the needs pertaining to HIV diagnosis disclosure among adolescents especially, the perinatally infected adolescents. This review summarizes some guidance points for developing a framework for HIV disclosure among the perinatally infected adolescents living in resource limited settings.

\section{Method}

A range of electronic databases, including the Cochrane Central Register of Controlled Trials (CENTRAL), MEDLINE (via Pub Med), and Google scholar were searched. The date range for the search was from 23rd June 1989 till 2nd August 2013. Specific terms/phrases for search were: 'HIV disclosure'; 'HIV disclosure among adolescent; HIV disclosure among children/ child'; 'impact of disclosure of HIV diagnosis among children' and 'concerns for HIV disclosure among children/ adolescents'. In this review we did not include disclosure to orphans or institutionalized children.

Duplicate articles were filtered out. Based on the inclusion criteria of English language, the articles in any other language were excluded. Theoretical papers and review articles were also excluded. Evaluation of study design, type of population studied viz. caregiver/adolescent/caregiver-adolescent dyads and salient findings related to the disclosure of the diagnosis of HIV to the children, study design, authors' details and year of publication were entered in a structured excel format. After reading, codes were developed and articles were categorized in those codes. 


\section{Results}

The searches between various electronic data bases led to the identification of 311 articles in which 20 duplicate articles were removed [Figure. 1].

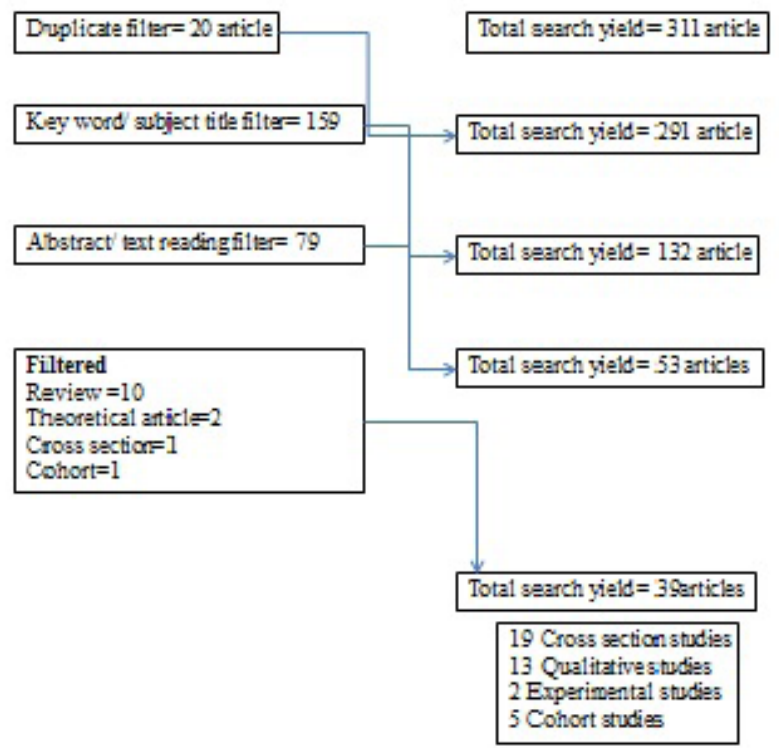

Figure 1: Review of articles searched from electronic data bases and showing the final yield of articles that were analyzed.

The final result was 291 articles of which 132 articles were identified based on key words and subject titles. The abstracts were read and based on the area of interest 53 articles were selected. Of these, 10 review articles; 2 theoretical articles, one non-relevant cross section and one non-relevant cohort study were excluded. A total of 39 articles were finally studied for this review.

In the year 1989, a study showed that HIV infected women might continue with their pregnancy owing to their own desire and other socio-cultural issues [13]. Thus, voluntarily or involuntarily, children were born of HIV infected parents and consequent to this is what we witness today-the perinatally infected adolescent population who have survived HIV because of HAART. Responsibility lies in mainstreaming this population by making them aware and empowering them with suitable strategies. Questions regarding when to disclose the diagnosis to the child was perceived as huge challenge because of the high level of public misunderstanding and fear regarding AIDS in early nineties [14]. However, disclosure of diagnosis among the perinatally infected children still remains a challenge even after more than three decades of the pandemic.

Disclosure was found to be positively related to social support, self-competence, and decreased problem behavior, except in the case of public disclosure [15]. Need for guidelines for disclosure emerged from several studies. Many studies reported disclosure of HIV diagnosis to children/adolescents [16-26,2,11] (Table 1). These studies included either caregivers only; children/ adolescent only or the child-caregiver dyads. The review revealed broad areas pertaining to HIV diagnosis disclosure as follows.

\begin{tabular}{|c|c|c|c|c|}
\hline $\begin{array}{l}\text { Location of } \\
\text { the study }\end{array}$ & $\begin{array}{l}\% \text { Disclosure of } \\
\text { HIV diagnosis } \\
\text { among children }\end{array}$ & $\begin{array}{l}\text { Study Sam- } \\
\text { ple \& size }\end{array}$ & Study design & Authors \\
\hline $\begin{array}{l}\text { A bidjan , } \\
\text { Côte d'Iv } \\
\text { oir e. }\end{array}$ & $63 \%$ & $\begin{array}{l}229 \text { adoles- } \\
\text { cents }\end{array}$ & $\begin{array}{l}\text { Cross sec- } \\
\text { tion }\end{array}$ & $\begin{array}{l}\text { Meless, } \\
\text { et al. } \\
2013[48]\end{array}$ \\
\hline $\begin{array}{l}\text { West } \\
\text { Africa }\end{array}$ & $33.50 \%$ & $\begin{array}{l}650 \text { adoles- } \\
\text { cents }\end{array}$ & Cohort & $\begin{array}{l}\text { Arrivé, } \\
\text { et al. } \\
2012[11]\end{array}$ \\
\hline $\begin{array}{l}\text { Ghana, } \\
\text { West } \\
\text { Africa }\end{array}$ & $21 \%$ & $\begin{array}{l}71 \text { caregiver- } \\
\text { child dyads }\end{array}$ & $\begin{array}{l}\text { Cross sec- } \\
\text { tion }\end{array}$ & $\begin{array}{l}\text { Kallem, } \\
\text { et al. } \\
2011[23]\end{array}$ \\
\hline $\begin{array}{l}\text { Rwanda, E } \\
\text { \& C Africa }\end{array}$ & $65 \%$ & $\begin{array}{l}1,034 \text { chil- } \\
\text { dren } 7-15 \\
\text { on HAART } \\
\text { and in the } \\
\text { pre-HAART } \\
\text { phase }\end{array}$ & $\begin{array}{l}\text { Cross sec- } \\
\text { tion }\end{array}$ & $\begin{array}{l}\text { Binagwa- } \\
\text { ho, et al. } \\
2012[26]\end{array}$ \\
\hline $\begin{array}{l}\text { Adis } \\
\text { Ababa, } \\
\text { Ethiopia }\end{array}$ & $16.30 \%$ & $\begin{array}{l}172 \text { parents/ } \\
\text { caregivers } \\
\text { of HIV- } \\
\text { infected } \\
\text { school-age } \\
\text { children }\end{array}$ & $\begin{array}{l}\text { Cross sec- } \\
\text { tion }\end{array}$ & $\begin{array}{l}\text { Abebe W, } \\
\text { Teferra S, } \\
2012[2]\end{array}$ \\
\hline Nigeria & $13.50 \%$ & $\begin{array}{l}83 \text { Caregiv- } \\
\text { ers of } 96 \\
\text { children }\end{array}$ & $\begin{array}{l}\text { Cross sec- } \\
\text { tion }\end{array}$ & $\begin{array}{l}\text { Brown, } \\
\text { et al. } \\
2011[22]\end{array}$ \\
\hline India & $\begin{array}{l}41.4 \%[75.3 \% \\
\text { inaccurate } \\
\text { information] }\end{array}$ & 145 children & $\begin{array}{l}\text { Cross sec- } \\
\text { tion }\end{array}$ & $\begin{array}{l}\text { Bhat- } \\
\text { tacharya. et } \\
\text { al.2011[34] }\end{array}$ \\
\hline India & $14 \%$ & 50 children & $\begin{array}{l}\text { Cross sec- } \\
\text { tion }\end{array}$ & $\begin{array}{l}\text { Singh, } \\
\text { et al. } \\
2009[21]\end{array}$ \\
\hline Thailand & $19.80 \%$ & $\begin{array}{l}\text { Primary car- } \\
\text { egivers of } 96 \\
\text { HIV-infect- } \\
\text { ed children } \\
\text { aged } 5 \text { years } \\
\text { and older }\end{array}$ & $\begin{array}{l}\text { Cross sec- } \\
\text { tion }\end{array}$ & $\begin{array}{l}\text { Boon- } \\
\text { Yasidhi, } \\
\text { et al. } \\
2005[19]\end{array}$ \\
\hline $\begin{array}{l}\text { United } \\
\text { States }\end{array}$ & $43 \%$ & $\begin{array}{l}85 \text { HIV- } \\
\text { infected, } \\
\text { school-age } \\
\text { patients }\end{array}$ & $\begin{array}{l}\text { Retrospec- } \\
\text { tive chart } \\
\text { review }\end{array}$ & $\begin{array}{l}\text { Mialky, } \\
\text { et al. } \\
2001[18]\end{array}$ \\
\hline $\begin{array}{l}\text { New York, } \\
\text { USA }\end{array}$ & $70 \%$ & $\begin{array}{l}196 \text { PLHIV+ } \\
\text { youth and } \\
\text { their car- } \\
\text { egivers }\end{array}$ & $\begin{array}{l}\text { Cross sec- } \\
\text { tion }\end{array}$ & $\begin{array}{l}\text { Santama- } \\
\text { ria, et al. } \\
2011[25]\end{array}$ \\
\hline $\begin{array}{l}\text { New York, } \\
\text { USA }\end{array}$ & $\begin{array}{l}41 \% \text { full disclo- } \\
\text { sure }\end{array}$ & $\begin{array}{l}73 \text { perina- } \\
\text { tally HIV } \\
\text { infected } 6 \\
\text { years and } \\
\text { older }\end{array}$ & $\begin{array}{l}\text { Prospective } \\
\text { cohort re- } \\
\text { ceiving care } \\
\text { at hospital }\end{array}$ & $\begin{array}{l}\text { Lee \& } \\
\text { Johann- } \\
\text { Liang, } \\
\text { 1999[35] }\end{array}$ \\
\hline $\begin{array}{l}\text { Newark, } \\
\text { USA }\end{array}$ & $\begin{array}{l}\text { 19\% partial } \\
\text { disclosure }\end{array}$ & $\begin{array}{l}42 \text { children } \\
\text { older than } 9 \\
\text { years }\end{array}$ & $\begin{array}{l}\text { Descriptive } \\
\text { cohort }\end{array}$ & $\begin{array}{l}\text { Grub- } \\
\text { man, et al. } \\
1995[16]\end{array}$ \\
\hline
\end{tabular}

Table1: Reported disclosure of HIV diagnosis among HIV infected children/ adolescents

\section{Pattern and approach}

The rate of disclosure was low with proportion of children/ adolescents who were not told/ were unaware about their HIV diagnosis ranged between $33 \%$ and $80.2 \%$ (mean $=61.6 \%$ ). In an African study, Vaz et al. [27] reported limited communication between children and their caregivers as well as their providers, before, during, and after the disclosure. In the same 
study, children shared that disclosure was largely a discrete event rather than a process. Another study echoes the same where the parents considered disclosure as a one-time event [28]. On the other hand, several reports point towards the need of a staged approach i.e. disclosure should be a process $[23,29,30]$.

Role of parents/ primary caregivers: Primary caregiver, generally a family member like father, mother, aunt or uncle emerged as the person who should disclose the HIV diagnosis $[20,22,2,29,31-33]$. In India, parents were preferred people to disclose but we found only two studies that reported disclosure among adolescents [21,34]. An anonymous survey of 64 primary health care workers and 131 community members from rural Eastern Zimbabwe showed that the most commonly preferred family members were father's sister (up to 37\%) and grandmother (up to $40 \%$ ) rather than the partner [20]. This study indicated higher rate of disclosure by caregivers who had higher education.

Disclosure poses complex challenges because of issues pertaining to transmissibility, maternal guilt, parents' own HIV status, and the potential for social stigma and isolation, among others. In the year 1999, concept of slow and partial disclosure came into being where partial disclosure was done among $19 \%$ of children and complete disclosure was done among $41 \%$ of the children older than 6 years [35]. The unmet need of guidance for diagnosis disclosure arises even today as the recent studies also show that disclosure among children/ adolescent was done partially [29]. Inaccurate disclosure was reported to be high in a study conducted among 145 HIV infected children studied [64/85 (75.3\%)] in India [34]. In another study from Thailand, it was reported that many of those care givers $(84.3 \%)$ who reported that the child did not know of his/ her diagnosis, had inaccurately explained to the child that he or she had some kind of disease such as allergy, lung, or liver disease [10]. A qualitative study conducted among adult New Yorkers brings out the complexities associated with disclosure decision making process where people either hide or provide selective information to manage stigma or partially disclose to have partial control of the information or complete disclosure is done representing stigma resistance [36]. Non disclosure or partial disclosure tends to leave child alone with his/ her questions, thus compromising disease knowledge with consequent effect on emotional/ physical growth, behavior, interpersonal relationship and school performance.

\section{Capacity building needs for conveying diagnosis}

Caregivers with higher education, reported more disclosure [25]. The parents who were illiterate and had rural background, depended solely on the health care providers for the disclosure of their children's diagnosis [26] bringing out the need to build capacities of the parents to communicate about the HIV diagnosis of their children. Strong views that caregivers require support from healthcare providers emerged from several studies [10,19,22,24,29,33,37]. Others have suggested that health care and social service providers could facilitate disclosure of illness to children with HIV [31]. Lack of communication about HIV/AIDS was shown to create a context of confusion and mistrust, which is detrimental to psychosocial development and coping, compromises disease knowledge, and increases vulnerability to risk behavior [38]. Thus, HIV knowledge enhancement along with enhancing communication skills of the parents/ family caregivers is recommended for the HIV diagnosis disclosure of children/ adolescents to take place in an ambient environment under parental care umbrella.

\section{Parents'/ Caregivers' capacity building}

Disclosure as a process appears to be a function of the age of the child, maturity of the child and feeling of protectiveness for the child. The basic social psychological problem emerges in caregivers' readiness to disclose the diagnosis. Biding for 'right time' was identified as another phenomenon linked to the problem of caregiver's readiness to disclose diagnosis to their children as they feel emotionally charged after learning about their diagnosis itself $[39,40,23]$. Younger age of the child was the common reason for non disclosure cited by the parents in India [34]. Duration of infection of parents had wider implications for making decisions about diagnosis disclosure to their children. In a survey conducted among affected and infected families, parents with future plans for their children had known about their HIV infection for significantly longer than those without [17]. Lack of knowledge of HIV and treatment among caregivers was another reason reported for non-disclosure [29]. In a qualitative study conducted in Kinshasa, Democratic Republic of the Congo, among HIV infected youth and the caregivers, $50 \%(8 / 16)$ of the youth wondered about the infection's origins [41] bringing forth the worse fear of parents but also a reminder that these perinatally HIV infected children are 'coming of age'. In a study in Vadodara city in India, authors have cautioned that tendency to blame parents if vertically affected needs to be considered while disclosure of HIV infection [perinatal] is contemplated among children [42]. A qualitative study in Congo demonstrated limited communications between the parent-child dyad before, during and after the disclosure [27]. Parent-child communication needs to be observed prior to finally preparing a parent/caregiver for disclosure otherwise inadequate communication between them may occur.

Cognitive ability of the child: Majority of the studies indicate that disclosure of HIV diagnosis to children is a process involving multiple stages. A number of studies focus on acceptable age of the child for disclosure $[17,18,38,41,21,43$ $45,34,22,23,25,2]$. Some reports indicate that disclosure should start at the age of 5 years and then full disclosure should be made at the age of 12 years [29]. Disclosure at the age of 12 years has also been recommended by WHO [46]. Overall, the recommended age for disclosure ranges between 10 years and 13 years. For example, in India, the mid teen years are considered the acceptable age of disclosure. In a prospective study, it was shown that the age at disclosure decreased significantly over time [44]. There were no statistical significant differences between pre-disclosure and post disclosure on the quality of life. This provides further demonstration of the importance of appropriate time of disclosure. 
From the providers' point of view the optimal age for general discussions about an HIV-infected child's health should happen around age 6 , but that specific discussions regarding HIV infection should be delayed to a median of 10 years [32]. In India, Bhattacharya et al. reported that the mean age of disclosure by parents was $9.1 \pm 1.4$ years [34]. Developmental issues are one of the common reasons for contemplating disclosure among caregivers. Thus growing age was the commonly cited reason across most of the studies. In a study, some girls believed disclosing one's HIV status to a male partner shifts the responsibility of preventing transmission to that partner [24]. This kind of perception indicates the need for an appropriate systematic disclosure process at right time.

Major concern about disclosure to children was the 'understanding level' of the child and their questionable capacity to keep a secret. Parents were afraid that the child would 'disclose' to someone [47]. Some of the common reasons for non-disclosing were also the concerns that the child was too young, that the child might be psychologically harmed [19,33,22,2,29]. Age appropriate information has been recommended [48].

Psychosocial Consequences: Majority of the caregivers do disclose the diagnosis to the child, usually with no ill effects [43]. Arrive et al. [11] showed that the youth became less anxious after disclosure. An intervention study conducted by Nicastro and colleagues confirms this finding [49]. They report a reduction in anxiety among parents after they disclosed the diagnosis to the HIV infected children in this study. In another prospective study conducted between 1987 and 2007 among HIV infected children/ adolescent in Brazil showed HIV-infection control among long term adolescent survivors and high scores of QOL [50]. However, high failure and school dropout rates were observed among the members of this cohort. Authors suggested early detection interventions are required for their school performance.

Children either ignored or forgot the disclosure. Therefore the interpretation of the disclosure process and the understanding of the diagnosis itself may be impacted by memory and developmental changes over time [51]. Motivated forgetting refers to a psychological defense mechanism in which people forget unwanted memories, either consciously or unconsciously [52] but memory remains stored [53]. Motivated forgetting could be the reason in such cases which needs to be explored to understand long term effects on child's behavior/ coping. Acceptance of HIV status would be a strong coping and adaptive strategy. For example in a Puerto Rican study conducted among $40 \mathrm{HIV}$ infected youth, $70 \%$ of the youth shared that they had feeling of normalcy six months after the disclosure of their HIV diagnosis [54].

\section{Adherence}

Initiation of HAART was found to be associated with the disclosure by the parents in India [34] especially when HAART is known to improve prognosis among HIV infected children $[55,56]$. Complete disclosure of HIV status provided by the caregivers to their children and strong parental relationships were related to good adherence [57]. In another study, children who were aware of their HIV status displayed fewer instances of frustration and conflict concerning adherence to their medications and within the child-caregiver relationship [58]. In a study conducted among caregivers reported that caregivers also felt disclosure increased adherence to antiretroviral therapy in 7 (63.6\%) of the 11 children on antiretroviral drugs in whom there was disclosure but no effect on the remaining [22]. In a qualitative study among caregivers who had disclosed the HIV diagnosis to the children, the common reasons spontaneously given for disclosing were the child's adherence to their treatment regimen $(5 / 16)$, and the need of the child to protect her/ him or stay healthy (5/16). In this study, complete disclosure of HIV status by caregivers to children and strong parental relationships were related to good adherence [41].In a quasi-experimental study conducted in Puerto Rico, 6 months after the disclosure, a positive change in medication adherence was felt by both the HIV infected adolescents (58\%) and their caregivers (59\%) in the study [54]. A Romanian retrospective study among 325 children on HAART also reports significant associations between not knowing the HIV diagnosis and death, and not knowing the HIV diagnosis and disease progression defined as either death or CD4 decline [59].

\section{Discussion}

Disclosure is about seeking support and preparing for disclosure may be linked to a range of factors including concerns regarding the consequences of disclosing. Uncertainties about the future often provoke a profound sense of loss of control. Studies show that children wish to be informed about their illness and plans for treatment [60]. In case of perinatal HIV infection, initially children might be ignorant but knowledge about HIV would be increasing as they grow and transition into adolescents and young adults. Paucity of concrete studies assessing awareness among this young population is a limitation.

This review shows that disclosure of HIV diagnosis among children and adolescents is very low especially in the resource limited setting. There is a paucity of studies on HIV diagnosis disclosure among adolescents in India. With the access to HAART, children have successfully survived HIV in the last decade and they are 'coming of age', ready to transition into adulthood and mainstreamed. The foremost need of this population is to understand their disease which would happen only if HIV diagnosis is disclosed to them. Caregivers either seemed to deny the need for disclosure or they lacked adequate skills and empowerment to take up the responsibility of disclosure. There is very little instruction available on how to approach HIV diagnosis communication with children and adolescents.

Coming of age with HIV: The classical developmental theory states that children do not fully comprehend the irreversibility of death until adolescence, approximately ages 11 to 16 years [61]. However, even much younger children (4-6 years) can have an advanced understanding of disease and the concept of death as they become alert to the changes in their bodies, their surroundings and translate reactions of health care providers and family [62]. Uncertainty is a major psychological burden both for children and adults with serious illnesses because they are limited in their capacity to obtain information that could 
potentially reassure them [63]. Children with perinatal HIV infection and Acquired Immunodeficiency Syndrome (AIDS) are living longer [64] but this review shows that many of them might not know anything about their disease because of various psychosocial reasons. It is noted that for the unique demands of a disease like HIV that pertains to sexual issues, HIV infected adolescents should be 'more' prepared, probably become 'more' aware of the sexual issues and grow 'more' mature than their HIV uninfected counterparts around them. A need for HIV diagnosis disclosure among children and adolescents emerges although several issues around it depend on available resource and cultural context (Table 1). HIV not only brings stigma into the near horizons of children and adolescent but it also brings a fear about parent-child relationship especially in the context of perinatal HIV infection. Developmental issues also pose challenges as the caregivers become anxious to disclose but they are afraid of inadvertent/ innocent disclosure by the child resulting into stigma and discrimination of the child as well as the family.

As compared to any other chronic disease, HIV/AIDS is different because of its socio-biological nature and as the children grow up with HIV, not disclosing their HIV diagnosis could be counterproductive. Guidelines need to be developed for disclosing HIV diagnosis. Studies have discussed several issues viz. appropriate time and age, opportunity, cognitive ability of children, preparation of caregivers, advantages and disadvantages of disclosure. Only two studies were found on disclosure issues among HIV infected adolescents/ children in India. Such studies are important within the local setting as proscriptions and prohibitions in one's own cultural context are critical for formulating disclosure guidelines. This is especially relevant for youth in the population. Studies on gender issues pertaining to disclosure remains a gap. Such studies may inform about cultural norms and help in dealing with biases.

Management issues: Another crucial issue in this scenario is the initiation of HAART and sustaining its adherence among children and adolescents. In the context of HAART, disclosure may have an important impact on disease progression and clinical management $[54,65]$. It has been shown to increase adherence. In a study conducted by Calabrese et al. [66] disclosure to at least one friend (versus no friends) was associated with less medication hiding, which was associated with higher CD4+ absolute counts and percentages but not viral load. In another study among children, knowledge of one's own HIV infection status showed association with delayed HIV disease progression [59]. In resource limited settings, disclosure of HIV status was identified as a factor strongly associated with better adherence [67] and higher retention in the care continuum [11]. As HIV-infected adolescents grow into adulthood, it becomes necessary to transfer them to adult care settings. This transition has been defined as "a multifaceted, active process that attends to the medical, psychosocial, and academic or vocational needs of adolescents as they move from the childto the adult-focused healthcare system. Health care transition should also facilitate transition in other areas of life as well" (e.g., work, community, and school.) [68].
Disclosure framework: Disclosure has also been shown to reduce anxiety among children and parents; it has shown to solve a multitude of adolescent problems; prevent transmission to others $[57,69,41]$ but still in this 4 th decade of the AIDS epidemic, disclosure is an issue indicating unmet needs of parents/ caregivers/ healthcare providers. Parents/ caregivers need support to engage in the disclosure process for their infected wards. Parents, who internalize HIV related stigma, hesitate to disclose the HIV diagnosis of children in order to protect them from stigma and discrimination. Another barrier to disclosure by parents was their limited disclosure skills. Studies from resource limited settings have shown poor knowledge among the parents or the primary caregivers to be a critical factor for disclosure. Thus, the parents need support for disclosure from health care providers [70]. There is dearth of guidelines for HIV diagnosis disclosure although some recommendations exist $[46,71]$ which can be adapted to include the ensuing key points within the local cultural context. The process of disclosure would entail two major considerations:

\section{Engage the primary caregiver}

The preparedness of parents or the caregivers is an issue of prime importance as they themselves might be infected. Their level of knowledge might not be adequate especially in the context of information overdose on the internet and children being more knowledgeable with usage of the internet information procurement. Parents need support for disclosure and they need to be prepared for the disclosure process. Hence the first step in the disclosure process would be to engage them and build their capacity for disclosure.

\section{Age appropriate disclosure}

Adolescence has emerged as 'the time' for disclosure. In general, disclosure is geared to a child's level of cognitive development [72] and psychosocial maturity which has been confirmed in case of HIV disclosure in this review. The majority of the papers indicate the early teens to be the time for disclosure. Disclosure becomes an issue as sexuality becomes a dominant developmental issue during adolescence [73]. However, most of the parents and caregivers advised age appropriate disclosure. Hence the disclosure process should start at different stages of adolescence and continue until they have appropriate cognition of the information provided. Mid teens could be the time when disclosure should be complete.

The stages of disclosure process requires three critical components of 'when'; 'what' and 'preserving parent-child relationship' delineated as follows:

\section{When to start engaging with adolescent}

Cues could be behavior change like tantrums or becoming secretive, not participating in family gatherings, becoming disinterested and 'new' behaviors. Maturity is another important parameter to be taken into consideration while contemplating disclosure. Developmental signs could be when the child starts talking about friends and peers, friendship with the opposite sex and his/ her ability to understand the disease could be when he/ she starts taking care of someone sick in the family. 


\section{What-Clear misconceptions}

With all types of media exposure, the child might have some or complete knowledge of HIV/AIDS. While initiating the process of disclosure, first explore what information the child has about HIV/ AIDS, about parents' sickness and follow with HIV infected individuals and what it means in terms of longevity, adherence to medications, nutrition, exercise and positive life style. Attitude towards parents and parent-adolescent communication could be important at this time.

\section{Preserve-Reinforce role played by parents in pro- viding care}

The major concern of parents regarding losing child's respect for themselves needs to be part of disclosure guidelines.

The views of Stanley Hall about adolescence being the stage of storm and stress [74] becomes more pronounced when one views 'Adolescence with HIV'. Other than infancy, no stage in human development results in such rapid or dramatic change as adolescence. Right from the pubertal milestones, body image till meeting life's goal becomes a major concern of adolescents. Not knowing about their HIV diagnosis or making a guess about it might be even more strenuous emotionally than coming to know of one's own HIV diagnosis. Research should focus on understanding the post disclosure reaction of children and growing up issues especially in context of their knowledge that they acquired this disease from their parents. In-depth exploration of post disclosure psychosocial state compared to predisclosure states would be useful to develop disclosure guidelines specific to the local socio-cultural context.

Finally HIV disclosure among adolescents would be a shared process between the caregivers and the health care providers as represented in the schema for disclosure in figure.2.

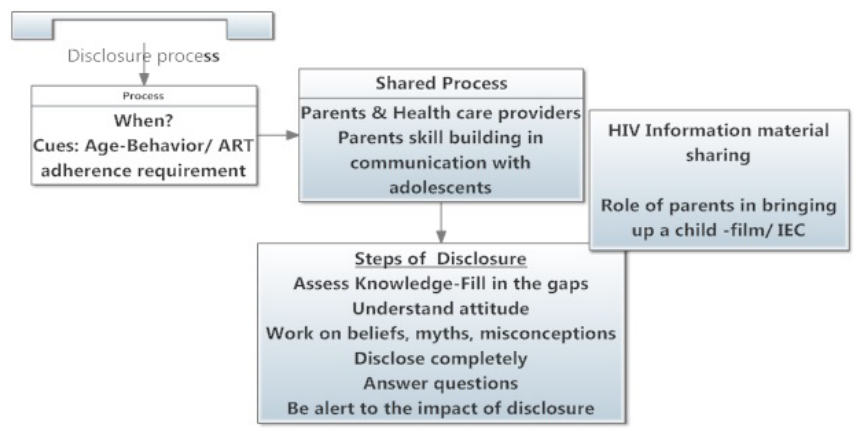

Figure 2: Schematic representation of process of perinatal HIV disclosure. Parents' preparedness is of prime importance for a successful disclosure. At both stages when parents are being prepared and when actual disclosure is taking place, information material on HIV should be used and parent-child bond should be reinforced.

The caregivers bring forth the apt time for disclosure while health care provider should assess parents' preparedness. Health care providers have a crucial role in preparing parents by enhancing their knowledge and prepare them to answer difficult questions. Education material especially electronic media could be used to bring in the much needed and much feared social issue of parent-child relationship in context of perinatal HIV infection.

\section{Conclusions}

Adolescents complete their physical, emotional and psychological journey to adulthood in a changing world that contains both opportunities and risks. New generations of adolescents with perinatal HIV infection are emerging with whom health services together with civil society can play an important role in helping them stay healthy. These adolescents are becoming sexually mature and must deal with the tremendous challenges of sexuality and (possibly) reproduction in the background of their HIV disease. Family has a crucial role in preparing adolescents for disclosure of their diagnosis of HIV. The parents/ caregivers need skills and capacity building to convey HIV diagnosis to their wards. Communication between parents and their children on issues of sexuality needs to be assessed prior to preparing them for disclosure. Capacity building of parents/ caregivers to enhance parent-adolescent communication is the need of the time.

\section{Acknowledgments}

I would like to thank Dr. AmeetaKalokhe, Emory University, for providing full text articles. I acknowledge Dr. Margaret Mead, the Anthropologist, whose work 'Coming of age in Samoa' inspired me to write this review. The title reflects the inspiration. I acknowledge the support received from Indian Council of Medical Research and Dr. R. S. Paranjape, Director, National AIDS Research Institute. I thank my colleagues Dr. Manisha Ghate and Dr. Sampada Dhayarkar for providing valuable critique that has strengthened this work.

\section{References}

1) Marston M, Becquet R, Zaba B, Moulton LH, Gray G, et al. (2011) Net survival of perinatally and postnatally HIV-infected children: a pooled analysis of individual data from sub-Saharan Africa. Int J Epidemiol 40: 385-396.

2) Abebe W, Teferra S (2012) Disclosure of diagnosis by parents and caregivers to children infected with HIV: prevalence associated factors and perceived barriers in Addis Ababa, Ethiopia. AIDS Care 24: 1097-1102.

3) Hazra R, Siberry GK, Mofenson LM (2010) Growing up with HIV: children, adolescents, and young adults with perinatally acquired HIV infection. Annu Rev Med 61: 169-185.

4) Mofenson LM, Cotton MF (2013) The challenges of success: adolescents with perinatal HIV infection. J Int AIDS Soc 16: 18650.

5) Wiener L, Mellins CA, Marhefka S, Battles HB (2007) Disclosure of an HIV diagnosis to children: history, current research, and future directions. J Dev Behav Pediatr 28: 155-166.

6) Slavin LA, O'Malley JE, Koocher GP, Foster DJ (1982) Communication of the cancer diagnosis to pediatric patients: impact in long term adjustment. Am J Psychiatry 139: 179-183.

7) Wiener L, Theut S, Steinberg SM, Riekert KA, Pizzo PA (1994) The HIVinfected child: parental responses and psychosocial implications. Am J Orthopsychiatry 64: 485-492.

8) de Martino, M., P. A. Tovo, et al. (2001) Puberty in perinatal HIV-1 infection: a multicentre longitudinal study of 212 children. AIDS 15: 1527-1534.

9) Louthrenoo O, Oberdorfer P, Sirisanthana V (2013) Psychosocial Functioning in Adolescents with Perinatal HIV Infection Receiving Highly Active Antiretroviral Therapy. J Int Assoc Provid AIDS Care.

10) Oberdorfer P, Puthanakit T, Louthrenoo O, Charnsil C, Sirisanthana V, et al. (2006) Disclosure of HIV/AIDS diagnosis to HIV-infected children in Thailand. J Paediatr Child Health 42: 283-288.

11) Arrive E, Dicko F, Amghar H, Aka AE, Dior H, et al. (2012) HIV status disclosure and retention in care in HIV-infected adolescents on antiretroviral therapy (ART) in West Africa. PLoS One 7: e33690. 
12) Barlow-Mosha L, Eckard AR, McComsey GA, Musoke PM, et al. (2013) Metabolic complications and treatment of perinatally HIV-infected children and adolescents. J Int AIDS Soc 16: 18600.

13) Selwyn PA, Carter RJ, Schoenbaum EE, Robertson VJ, Klein RS, et al. (1989) Knowledge of HIV antibody status and decisions to continue or terminate pregnancy among intravenous drug users. JAMA 261: 3567-3571.

14) Spiegel L, Mayers A (1991) Psychosocial aspects of AIDS in children and adolescents. Pediatr Clin North Am 38: 153-167.

15) Battles HB, Wiener LS (2002) From adolescence through young adulthood: psychosocial adjustment associated with long-term survival of HIV. J Adolesc Health 30: 161-168.

16) Grubman S, Gross E, Lerner-Weiss N, Hernandez M, McSherry GD, et al. (1995) Older children and adolescents living with perinatally acquired human immunodeficiency virus infection. Pediatrics 95: 657-663.

17)Thorne C, Newell ML, Peckham CS, et al. (2000) Disclosure of diagnosis and planning for the future in HIV-affected families in Europe. Child Care Health Dev 26: 29-40.

18) Mialky E, Vagnoni J, Rutstein R, et al. (2001) School-age children with perinatally acquired HIV infection: medical and psychosocial issues in a Philadelphia cohort. AIDS Patient Care STDS 15: 575-579.

19) Boon-Yasidhi V, Kottapat U, Durier Y, Plipat N, Phongsamart W, et al. (2005) Diagnosis disclosure in HIV-infected Thai children. J Med Assoc Thai 88: S100-S105

20) De Baets AJ, Sifovo S, Parsons R, Pazvakavambwa IE (2008) HIV disclosure and discussions about grief with Shona children: a comparison between health care workers and community members in Eastern Zimbabwe. Soc Sci Med 66: 479-491.

21) Arun S, Singh AK, Lodha R, Kabra SK (2009) Disclosure of the HIV infection status in children. Indian J Pediatr 76: 805-808.

22) Brown BJ, Oladokun RE, Osinusi K, Ochigbo S, Adewole IF, et al. (2011) Disclosure of HIV status to infected children in a Nigerian HIV Care Programme. AIDS Care 23: 1053-1058.

23) Kallem S, Renner L, Ghebremichael M, Paintsil E (2011) Prevalence and pattern of disclosure of HIV status in HIV-infected children in Ghana. AIDS Behav 15: 1121-1127.

24) Marhefka SL, Valentin CR, Pinto RM, Demetriou N, Wiznia A, et al. (2011) I feel like I'm carrying a weapon." Information and motivations related to sexual risk among girls with perinatally acquired HIV. AIDS Care 23: 1321-1328.

25) Santamaria EK, Dolezal C, Marhefka SL, Hoffman S, Ahmed Y, et al. (2011) Psychosocial implications of HIV serostatus disclosure to youth with perinatally acquired HIV. AIDS Patient Care STDS 25: 257-264.

26) Binagwaho A, Murekatete I, Rukundo A, Mugwaneza P, Hinda R, et al. (2012) Factors Associated With Disclosure of Hiv Status Among Hivpositivechildren In Rwanda. Rwanda Medical Journal 69: 9-15.

27) Vaz LM, Eng E, Maman S, Tshikandu T, Behets F (2010) Telling children they have HIV: lessons learned from findings of a qualitative study in subSaharan Africa. AIDS Patient Care STDS 24: 247-256.

28) Chew J, Beng AL, Mun S (2012) Parental concerns about disclosure of a child's HIV/AIDS status in Singapore. Soc Work Health Care 51: 5-21.

29) Heeren GA, Jemmott JB, Sidloyi L, Ngwane Z (2012) Disclosure of HIV Diagnosis to HIV-Infected Children in South Africa: Focus Groups for Intervention Development. Vulnerable Child Youth Stud 7: 47-54.

30) Cantrell K, Patel N, Mandrell B, Grissom S (2013) Pediatric HIV Disclosure: A Process-Oriented Framework. AIDS Educ Prev 25: 302-314.

31) Kouyoumdjian FG, Meyers T, Mtshizana S (2005) Barriers to disclosure to children with HIV. J Trop Pediatr 51: 285-287.

32) Myer L, Moodley K, Hendricks F, Cotton M (2006) Healthcare providers' perspectives on discussing HIV status with infected children. J Trop Pediatr 52: 293-295.

33) Vreeman RC, Nyandiko WM, Ayaya SO, Walumbe EG, Marrero DG, et al. (2010) The perceived impact of disclosure of pediatric HIV status on pediatric antiretroviral therapy adherence, child well-being, and social relationships in a resource-limited setting. AIDS Patient Care STDS 24: 639-649.

34) Bhattacharya M, Dubey AP, Sharma M, et al. (2011) Patterns of diagnosis disclosure and its correlates in HIV-Infected North Indian children. J Trop
Pediatr 57: 405-411.

35) Lee CL, Johann-Liang R (1999) Disclosure of the diagnosis of HIV/AIDS to children born of HIV-infected mothers. AIDS Patient Care STDS 13: 41-45. 36) Poindexter CC, Shippy RA (2010) HIV diagnosis disclosure: stigma management and stigma resistance. J Gerontol Soc Work 53: 366-381.

37) Vreeman RC, Gramelspacher AM, Gisore PO, Scanlon ML, Nyandiko WM, et al. (2013) Disclosure of HIV status to children in resource-limited settings: a systematic review. J Int AIDS Soc 16: 18466.

38) Abadía-Barrero CE, Larusso MD (2006) The disclosure model versus a developmental illness experience model for children and adolescents living with HIV/AIDS in Sao Paulo, Brazil. AIDS Patient Care STDS 20: 36-43.

39) Wiener LS, Battles HB, Heilman NE (1998) Factors associated with parents' decision to disclose their HIV diagnosis to their children. Child Welfare 77: 115-135.

40) Ledlie SW (1999) Diagnosis disclosure by family caregivers to children who have perinatally acquired HIV disease: when the time comes. Nurs Res 48: 141-149.

41) Vaz L, Corneli A, Dulyx J, Rennie S, Omba S, et al. (2008) The process of HIV status disclosure to HIV-positive youth in Kinshasa, Democratic Republic of the Congo. AIDS Care 20: 842-852.

42) Naswa S, Marfatia YS (2010) Adolescent HIV/AIDS: Issues and challenges. Indian J Sex Transm Dis 31: 1-10.

43) Wiener LS, Battles HB, Heilman N, Sigelman CK, Pizzo PA (1996) Factors associated with disclosure of diagnosis to children with HIV/AIDS. Pediatr AIDS HIV Infect 7: 310-324.

44) Butler AM, Williams PL, Howland LC, Storm D, Hutton N, et al. (2009) Impact of disclosure of HIV infection on health-related quality of life among children and adolescents with HIV infection. Pediatrics 123: 935-943.

45) Corneli A, Vaz L, Dulyx J, Omba S, Rennie S, et al. (2009) The role of disclosure in relation to assent to participate in HIV-related research among HIV-infected youth: a formative study. J Int AIDS Soc 12: 17

46) WHO (2011) Guideline on HIV disclosure counselling for children up to 12 years of age. ISBN: 978924150286 3. Geneva, WHO.

47) Buchanan AL, Montepiedra G, Sirois PA, Kammerer B, Garvie PA, et al. (2012) Barriers to medication adherence in HIV-infected children and youth based on self- and caregiver report. Pediatrics 129: e1244-e1251.

48) Meless GD, Aka-Dago-Akribi H, Cacou C, Eboua TF, Aka AE, et al. (2013) Notification of HIV status disclosure and its related factors in HIV-infected adolescents in 2009 in the Aconda program (CePReF, CHU Yopougon) in Abidjan, Cote d'Ivoire, The PRADO-CI Study. J Int AIDS Soc 16: 18569.

49) Nicastro E, Continisio GI, Storace C, Bruzzese E, Mango C, et al. (2013) Family group psychotherapy to support the disclosure of HIV status to children and adolescents. AIDS Patient Care STDS 27: 363-369.

50) Souza E, Santos N, Valentini S, Silva G, Falbo A (2010) Long-term followup outcomes of perinatally HIV-infected adolescents: infection control but school failure. J Trop Pediatr 56: 421-426.

51) Mawn BE (2011) Children's voices: living with HIV. MCN Am J Matern Child Nurs 36: 368-372.

52) Weiner B (1968) Motivated forgetting and the study of repression. J Pers 36: 213-234.

53) Anderson MC (2003) Rethinking Interference Theory: Executive control and the mechanisms of forgetting. J Mem Lang 49: 415-445.

54) Blasini I, Chantry C, Cruz C, Ortiz L, Salabarría I, et al. (2004) Disclosure model for pediatric patients living with HIV in Puerto Rico: design, implementation, and evaluation. J Dev Behav Pediatr 25: 181-189.

55) Patel K, Hernán MA, Williams PL, Seeger JD, McIntosh K, et al. (2008) Long-term effectiveness of highly active antiretroviral therapy on the survival of children and adolescents with HIV infection: a 10-year follow-up study. Clin Infect Dis 46: 507-515.

56) Banerjee T, Pensi T, Banerjee D, Grover G (2010) Impact of HAART on survival, weight gain and resting energy expenditure in HIV-1-infected children in India. Ann Trop Paediatr 30: 27-37.

57) Bikaako-Kajura W, Luyirika E, Purcell DW, Downing J, Kaharuza F, et al. (2006) Disclosure of HIV status and adherence to daily drug regimens among 
HIV-infected children in Uganda. AIDS Behav 10: S85-S93.

58) Fetzer BC, Mupenda B, Lusiama J, Kitetele F, Golin C, et al. (2011) Barriers to and facilitators of adherence to pediatric antiretroviral therapy in a subSaharan setting: insights from a qualitative study. AIDS Patient Care STDS 25: 611-621.

59) Ferris, M., K. Burau, et al. (2007). "The influence of disclosure of HIV diagnosis on time to disease progression in a cohort of Romanian children and teens." AIDS Care 19(9): 1088-1094.

60) Wolfe, J., S. Friebert, et al. (2002). "Caring for children with advanced cancer integrating palliative care." Pediatr Clin North Am 49(5): 1043-1062.

61) Piaget, J. (1929). The child's conception of the world. London, UK, Routledge \& Kegan Paul.

62) Sahler, O. J., G. Frager, et al. (2000). "Medical education about end-of-life care in the pediatric setting: Principles, challenges, and opportunities." Pediatrics 105: 575 -584.

63) Beale, E. A., F. B. Walter, et al. (2005). "Silence Is Not Golden: Communicating With Children Dying From Cancer " Journal of Clinical Oncology 23 (15): 3629-3631.

64) Lesch, A., L. Swartz, et al. (2007). "Paediatric HIV/AIDS disclosure: towards a developmental and process-oriented approach." AIDS Care 19(6): 811-816.

65) Moodley, K., L. Myer, et al. (2006). "Paediatric HIV disclosure in South Africa -- caregivers' perspectives on discussing HIV with infected children." S Afr Med J 96(3): 201-204.

66) Calabrese, S. K., S. Martin, et al. (2012). "Diagnosis disclosure, medication hiding, and medical functioning among perinatally infected, HIV-positive children and adolescents." AIDS Care 24(9): 1092-1096.
67) Haberer, J. E. C., A. Walker A. S. Ngambi, M. Ferrier, A. Mulenga V. et al . (2011). "Excellent adherence to antiretrovirals in HIV + Zambian children is compromised by disrupted routine, HIV non disclosure, an d paradoxical income effects. ." PLoS On e 6(4).

68) Reiss, J. and R. Gibson (2002). "Health care transition: Destinations unknown. ." Pediatrics 110: 1307-1314.

69) Salter-Goldie, R. K., S.M. Smith, M.L. Bitnun, A. Brophy, J et al. (2007). "Disclosing HIV Diagnosis to Infected Children: A Health Care Team's Approach." Vulnerable Children and Youth Studies: An International Interdisciplinary Journal for Research, Policy and Care 2(1): 12-16.

70) Madiba, S. (2013). "The impact of fear, secrecy, and stigma on parental disclosure of HIV status to children: a qualitative exploration with HIV positive parents attending an ART clinic in South Africa." Glob J Health Sci 5(2): 49-61.

71) Institute, D. o. H. A. (2013). Disclosure of HIV to Perinatally Infected Children and Adolescents. HIV Clinical Reseource, New York Department of Health AIDS Institute. 2013.

72) Woodard, L. J. P., R.J. (1992). "The disclosure of the diagnosis of cancer." Prim Care 19: 657-663.

73) Nishi, E. A., N. Cincotta, et al. (2004). Disclosure in a new context: HIV infected children aging into adolescence. International Conference on AIDS; Jul 11-16; 15: abstract no D10681.

74) Hall, G. S. (1904). Adolescence: Its psychology and its relations to physiology, anthropology, sociology, sex, crime, religion, and education : . New York, D.Appleton \& Co. 